\title{
PT
}

M. ĐURIŠ, Z. ARSENIJEVIĆ, D. POVRENOVIĆ,

T. KALUĐEROVIĆ RADOIČIĆ

https://doi.org/102409/ptc.019.31.2.14

\section{Drying of waste water treatment sludge in fluidized bed of inert particles}

W aste water treatment sludge is generated in increasing quantities, as the amount of treated municipal and industrial waste water increases. Also, the requirements concerning the conditions of sludge storage/landfill or reuse are growing. Due to these reasons, new solutions regarding sludge treatment, management and utilization are needed [1]. The benefits of drying waste water treatment sludge can be seen in several aspects: the dried sludge can be stored for longer periods of time and further used as an organic fertilizer, it can be a source of useful (active) microorganisms that can be reused in waste water treatment. Drying also enables incineration or co-incineration of sludge. Sludge drying process reduces mass and volume of the product, making its storage, transport, packaging and retail easier [2-4].

\section{1}

\section{INTRODUCTION}

The choice of drying equipment that can be used for waste water sludge drying is wide. As the process of drying is one of the most energy-consuming unit operations, the choice of drying equipment is mainly based on its efficiency. An efficient drying system should meet several conditions: high values of heat and mass transfer coefficients, high contact area, high input of heat carrier gas, uniform temperature distribution over the drying chamber, the use of concentrated suspensions (as high as possible) in order to minimize water amount which should be evaporated and the use high inlet air temperature, as much as possible. Although there are hundreds of dryers actually used in industry, the research efforts are associated with the development of more sophisticated and efficient systems [57]. Particularly, with respect to the drying of solutions, suspensions and pastes, the use of fluidized, spouted, vibro-fluidized and agitated beds of inert particles is very important alternative to the classic drying technologies [8-12].

In this paper, experimental investigation of the efficiency of drying of municipal waste water treatment sludge was performed in a pilot scale fluidized bed dryer with inert glass particles. The capacity of the fluidized bed dryer was up to $20 \mathrm{kgH}_{2} \mathrm{O} / \mathrm{h}$ of evaporated water. Inert particles used were glass spheres of the diameter of $1.94 \mathrm{~mm}$. Waste water treatment sludge with dry mass concentration from 1-4\% was used in the experiments.

\section{EXPERIMENTAL}

Drying of waste water sludge was performed in the pilot plant system shown in Fig.1. The waste water sludge used was obtained from a municipal waste water treatment facility, after it was used in the biological treatment of the municipal waste water. The dry matter contents of the sludge ranged from 1 to $4 \%$.

The experimental system consisted of a cylindrical column of the diameter $\mathrm{Dc}=215 \mathrm{~mm}$ and height $\mathrm{H}=300 \mathrm{~mm}$. As inert particles, glass spheres of mean diameter $\mathrm{dp}=1.94 \mathrm{~mm}$ and density of $2460 \mathrm{~kg}$ / $\mathrm{m}^{3}$ were used. Air flow rate was kept constant during the experiments, at $270 \mathrm{~m}^{3} / \mathrm{h}$ (at ambient temperature). Inlet air temperature $\left(\mathrm{T}_{\mathrm{gi}}\right)$ was varied between 130 and $220{ }^{\circ} \mathrm{C}$, whereas the drying temperature (equal to the outlet air temperature, $\mathrm{T}_{\text {ge }}$ ) was in the range of 61 to $91{ }^{\circ} \mathrm{C}$. The feed material was pumped into the bed using a peristaltic pump and the feed inlet was located $100 \mathrm{~mm}$ above the gas distributor. The suspension flow rate was regulated to keep the pre-set drying temperature constant.

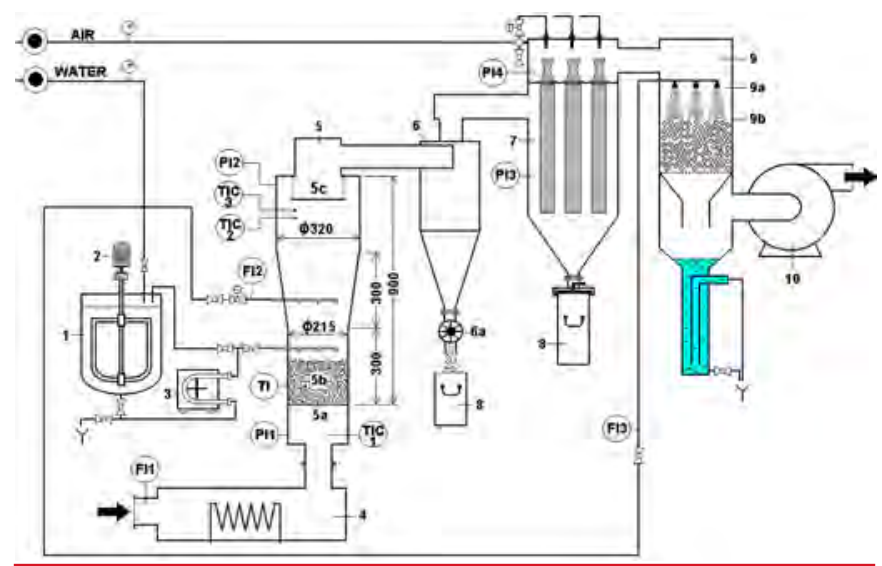

Figure 1: Schematic diagram of the drying system (1-tank, 2-agitator, 3-pump, 4-air heater, 5-fluidization column, 5a-distributor, 5b-Inert particles, 5c-deflector, 6-cyclone, 6a-rotary valve, 7-bag filter, 8-product containers, 9-scrubber, 9a-nozzle, 9b-packing, 10-blower)

Dry product is separated from the air stream using cyclone and bag filter. Before leaving the system, the exhaust air passes through a packed bed scrubber in order to remove any remaining particles. Temperature controller TIC1 is used to maintain the inlet air temperature at the desired level. Temperature controller TIC2, 
which is located $0.7 \mathrm{~m}$ above the distributor plate and connected with peristatic pump is used to keep the drying temperature at a desired constant level, by varying the sludge feed rate. The role of the temperature controller TIC3 is to prevent overheating of the bed, in the case of feeding device failure, by introducing pure water into the system. During the experiments, the inlet air temperature and bed temperature were continuously recorded using data acquisition system.

\section{RESULTS AND DISCUSSION}

\subsection{Temperature profiles during experiments}

Drying experiments were performed continuously. The temperature profiles were monitored during the experiments, as shown in Fig. 2. As can be seen from the figure, both the inlet air temperature (TIC 1) and the drying temperature (TIC 2) are kept constant, with drying temperature showing some variations due to the fact that it is regulated by regulating the sludge flow rate. As the fluidized bed is well mixed, the drying temperature is the same as the outlet air temperature.

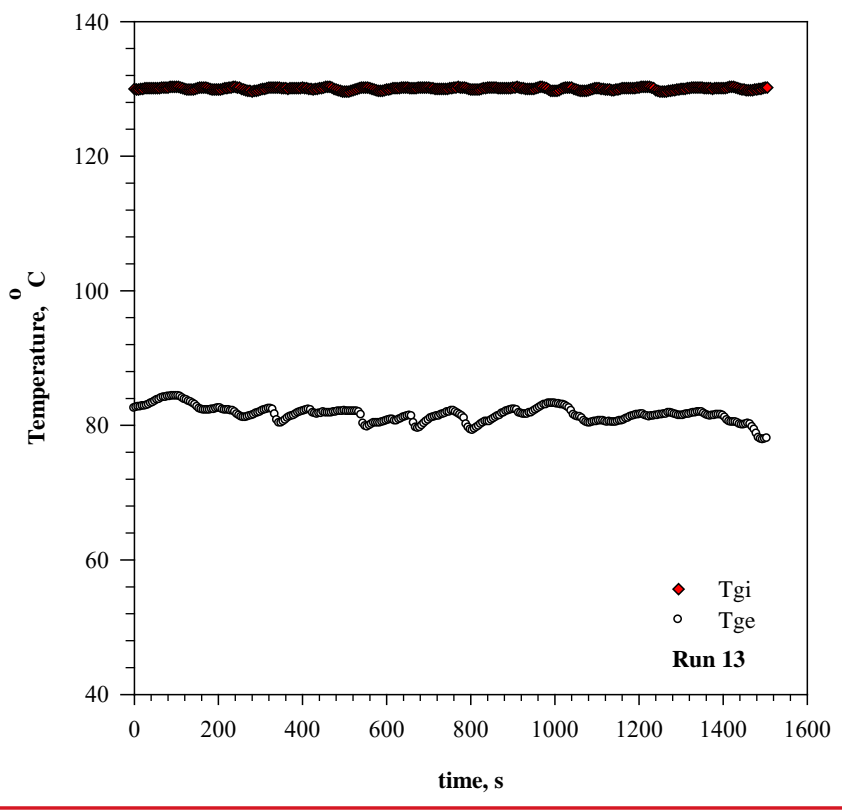

Figure 2: Example of the recorded temperature profile (experimental run 13)

\subsection{Experimental results}

The experimental conditions of the 14 experiments performed are shown in Table 1. As can be seen from the table, waste water sludge of three different concentration was dried, with dry matter content of $0.01,0.02$ and $0.04 \mathrm{kgdm} / \mathrm{kg}_{\mathrm{H} 2 \mathrm{O}}$ at different inlet air temperatures $\left(130,160,190\right.$ and $\left.220^{\circ} \mathrm{C}\right)$. Drying temperatures, which are the same as outlet air temperatures and suspension flow rates are also shown in Table 1, as well as the densities of the waste water sludge suspension and the final product.

The product moisture content as a function of drying temperature is shown in Fig. 3. As can be seen from Fig. 3, the moisture content decreases with the increase of drying temperature, however this parameter is also influenced by the temperature difference between the inlet and outlet air temperatures, so for a single drying temperature, there are distinct values of product moisture content for different inlet air temperatures.

Table 1. Experimental results

\begin{tabular}{|c|c|c|c|c|c|c|c|}
\hline Run & $\begin{array}{c}\text { Dry } \\
\text { matter } \\
\text { content } \\
\mathbf{y}_{0} \\
\text { [kgdm/ } \\
\left.\text { kg }_{\mathrm{H} 2 \mathrm{O}}\right]\end{array}$ & $\begin{array}{c}\text { Air } \\
\text { flowrate } \\
\text { (at } \mathrm{T}_{0} \text { ) } \\
\mathbf{V}_{0} \\
{\left[\mathrm{~m}^{3} / \mathrm{h}\right]}\end{array}$ & $\begin{array}{l}\text { Suspen- } \\
\text { sion } \\
\text { flowrate } \\
\text { Vsus } \\
\text { [l/h] }\end{array}$ & $\begin{array}{c}\text { Suspen- } \\
\text { sion } \\
\text { density } \\
\rho_{\text {sus }} \\
{\left[\mathrm{kg} / \mathrm{m}^{3}\right]}\end{array}$ & $\begin{array}{c}\text { Inlet air } \\
\text { tempera- } \\
\text { ture } \\
\mathrm{T}_{\mathrm{gi}} \\
{\left[{ }^{\circ} \mathrm{C}\right]}\end{array}$ & $\begin{array}{c}\text { Drying } \\
\text { tempera- } \\
\text { ture } \\
\mathbf{T}_{\mathrm{ge}} \\
{\left[{ }^{\circ} \mathrm{C}\right]}\end{array}$ & $\begin{array}{c}\text { Dried } \\
\text { product } \\
\text { bulk } \\
\text { density } \\
\rho_{d m} \\
{\left[\mathrm{~kg} / \mathrm{m}^{3}\right]}\end{array}$ \\
\hline 1 & 0.01 & 270 & 5.3 & 969.6 & 130 & 82 & 548.77 \\
\hline 2 & 0.01 & 270 & 7.6 & 969.6 & 130 & 61 & 602.33 \\
\hline 3 & 0.01 & 270 & 4.8 & 969.6 & 130 & 71 & 561.91 \\
\hline 4 & 0.01 & 270 & 10.8 & 963.5 & 160 & 62 & 611.35 \\
\hline 5 & 0.01 & 270 & 13.2 & 963.5 & 190 & 61 & 652.06 \\
\hline 6 & 0.01 & 270 & 9.7 & 963.5 & 220 & 62 & 601.85 \\
\hline 7 & 0.04 & 270 & 7.6 & 976.1 & 160 & 92 & 581.02 \\
\hline 8 & 0.04 & 270 & 11.2 & 976.1 & 190 & 91 & 499.56 \\
\hline 9 & 0.04 & 270 & 13.8 & 976.1 & 220 & 91 & 448.83 \\
\hline 10 & 0.04 & 270 & 12.2 & 976.1 & 130 & 91 & 502.21 \\
\hline 11 & 0.02 & 270 & 7.3 & 969.8 & 130 & 61 & 585.11 \\
\hline 12 & 0.02 & 270 & 6.6 & 969.8 & 130 & 72 & 605.27 \\
\hline 13 & 0.02 & 270 & 5.5 & 969.8 & 130 & 81 & 536.36 \\
\hline 14 & 0.02 & 270 & 4.3 & 969.8 & 130 & 91 & 467.23 \\
\hline
\end{tabular}

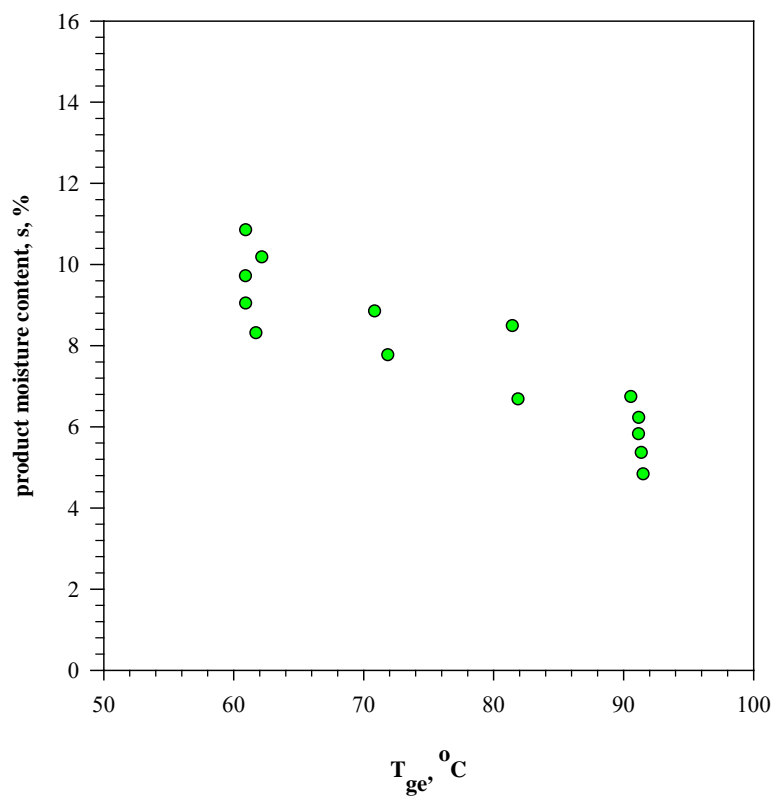

Figure 3: Residual water content as a function of drying temperature 


\section{PT Procesne tehnologije}

\subsection{Specific water evaporation rate and heat con- sumption}

Specific water evaporation rate $\left.\left(\mathrm{kg}_{\mathrm{H} 2 \mathrm{O}} / \mathrm{m}^{2} \mathrm{~h}\right)\right)$ calculated per unit of gas distributor cross-sectional area as a function of the temperature difference between the inlet and outlet air temperatures is shown in Fig. 4. As expected, the evaporation rate is directly proportional to the temperature difference. The highest evaporation rate in our experiments was $356 \mathrm{~kg}_{\mathrm{H} 2 \mathrm{O}} / \mathrm{m}^{2} \mathrm{~h}$.

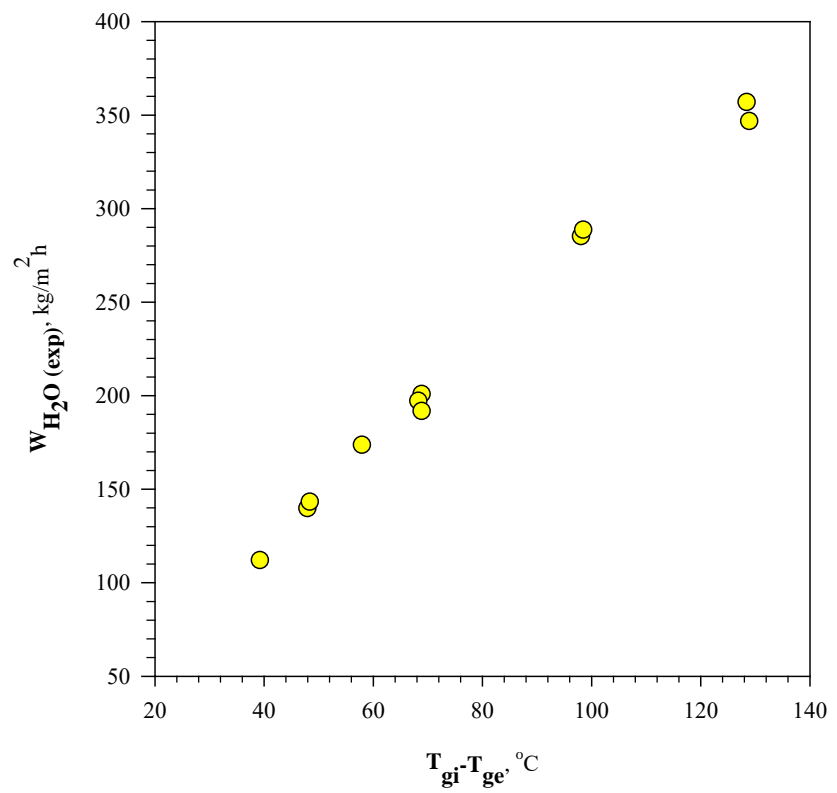

Figure 4: Specific water evaporation rate as a function of the temperature difference between inlet and outlet air temperatures

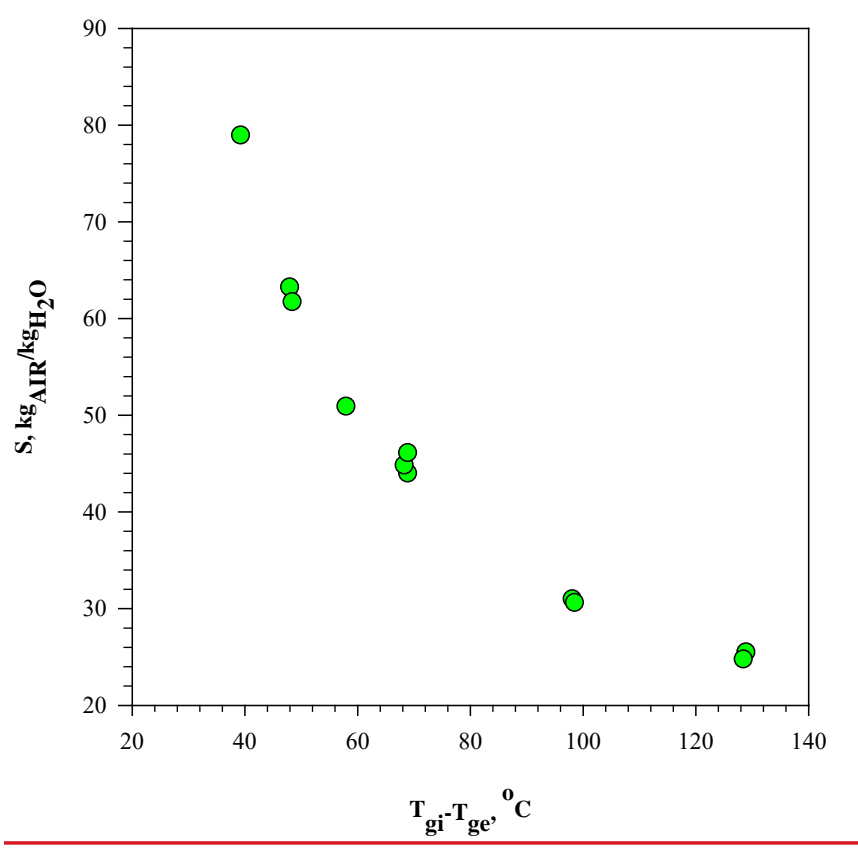

Figure 5: Specific air consumption as a function of the temperature difference between inlet and outlet air temperatures
Specific air consumption as a function of the temperature difference between inlet and outlet air temperatures is shown in Fig. 5. The air consumption rate decreases with temperature difference.

\subsection{Heat and mass balance of the system}

Theoretically, water evaporation capacity can be determined from the overall heat balance:

$$
G_{v} c_{v}\left(T_{g i}-T_{g e}\right)=G_{d m} c_{d m}\left(T_{g e}-T_{0}\right)+G_{H_{2} O}\left[c_{H_{2} O}\left(T_{g e}-T_{0}\right)+r_{H_{2} O}\right]+Q_{g}
$$

where $G_{v}$ - is air mass flowrate, $G_{d m}$ - mass flowrate of dry matter, $\mathrm{G}_{\mathrm{H} 2 \mathrm{O}}$ - water mass flowrate, $\mathrm{r}_{\mathrm{H} 2 \mathrm{O}}$ - latent heat of water evaporation and $\mathrm{Q}_{\mathrm{g}}$ - heat losses.

Since

$G_{s u s}=G_{d m}+G_{H_{2} O}$

and if water content is defined as $\mathrm{x}=\mathrm{G}_{\mathrm{H} 2 \mathrm{O}} / \mathrm{G}_{\text {sus }}$ it follows that $\mathrm{G}_{\mathrm{dm}}$ $=(1-\mathrm{x}) \mathrm{G}_{\mathrm{sus}}=[(1-\mathrm{x}) / \mathrm{x}] \mathrm{G}_{\mathrm{H} 2 \mathrm{O}}$. Using these relationships, equation (1) becomes

$$
W_{\mathrm{H}_{2} \mathrm{O}}=\frac{G_{\mathrm{H}_{2} \mathrm{O}}}{A_{c}}=\frac{1}{A_{c}} \cdot \frac{G_{v} c_{v}\left(T_{g i}-T_{g e}\right)-Q_{g}}{[(1-x) / x] c_{d m}\left(T_{g e}-T_{0}\right)+c_{\mathrm{H}_{2} \mathrm{O}}\left(T_{g e}-T_{0}\right)+r_{\mathrm{H}_{2} \mathrm{O}}}
$$

where $\mathrm{W}_{\mathrm{H} 2 \mathrm{O}}$ is specific water evaporation rate and $\mathrm{A}_{\mathrm{c}}$ is column cross-sectional area.

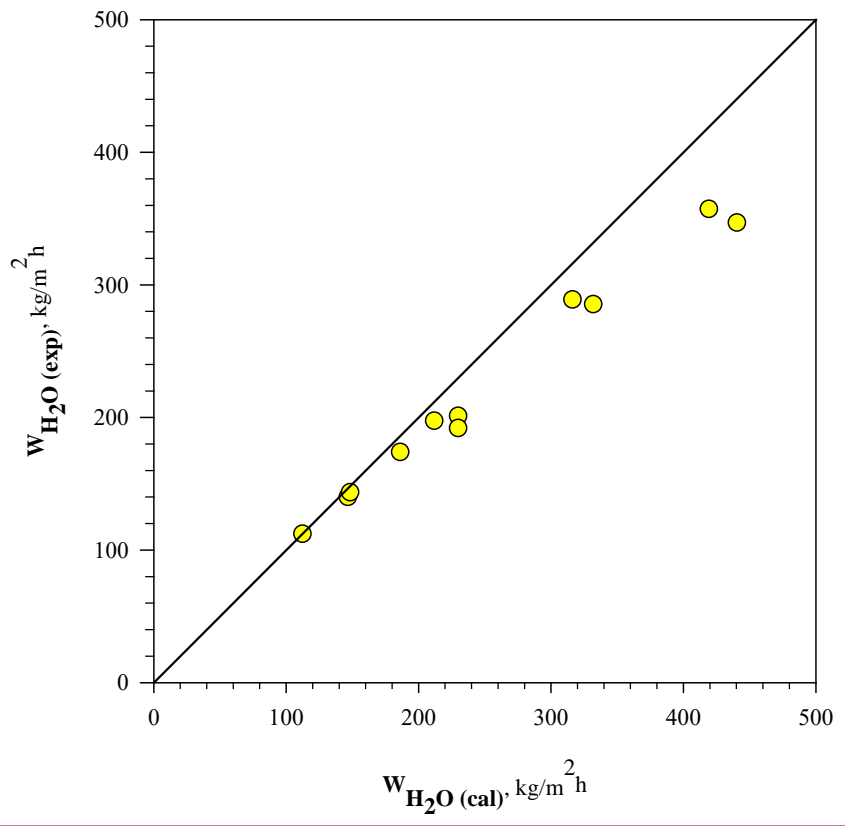

Figure 6: Comparison of experimental and calculated values of $\mathrm{W}_{\mathrm{H} 2 \mathrm{O}}$

For a fixed geometry of the fluidized bed $\left(A_{c}\right)$, the air flowrate, i.e., superficial air velocity, follows from the fluid bed mechanics and usually should be $2-3$ times higher than the minimum fluidization velocity $\left(\mathrm{U}_{\mathrm{mF}}\right)$. Since the outlet air temperature $\left(\mathrm{T}_{\mathrm{ge}}\right)$ is selected 
according to thermal stability of the drying material and a desired residual moisture content, Eq. (3) gives the simple relationship between inlet air temperature $\left(\mathrm{T}_{\mathrm{gi}}\right)$ and specific water evaporation rate $\left(\mathrm{W}_{\mathrm{H} 2 \mathrm{O}}\right)$.

Fig. 6. gives the comparison between experimental and calculated values of $\mathrm{W}_{\mathrm{H} 2 \mathrm{O}}$, using estimated value of $\mathrm{c}_{\mathrm{dm}}=1200 \mathrm{~kJ} / \mathrm{kgK}$. As can be seen the agreement is very good, although calculated values are systematically slightly above experimental ones (12.2\% on average) due to the fact that in calculations heat losses were neglected. The maximum deviation is $27.4 \%$.

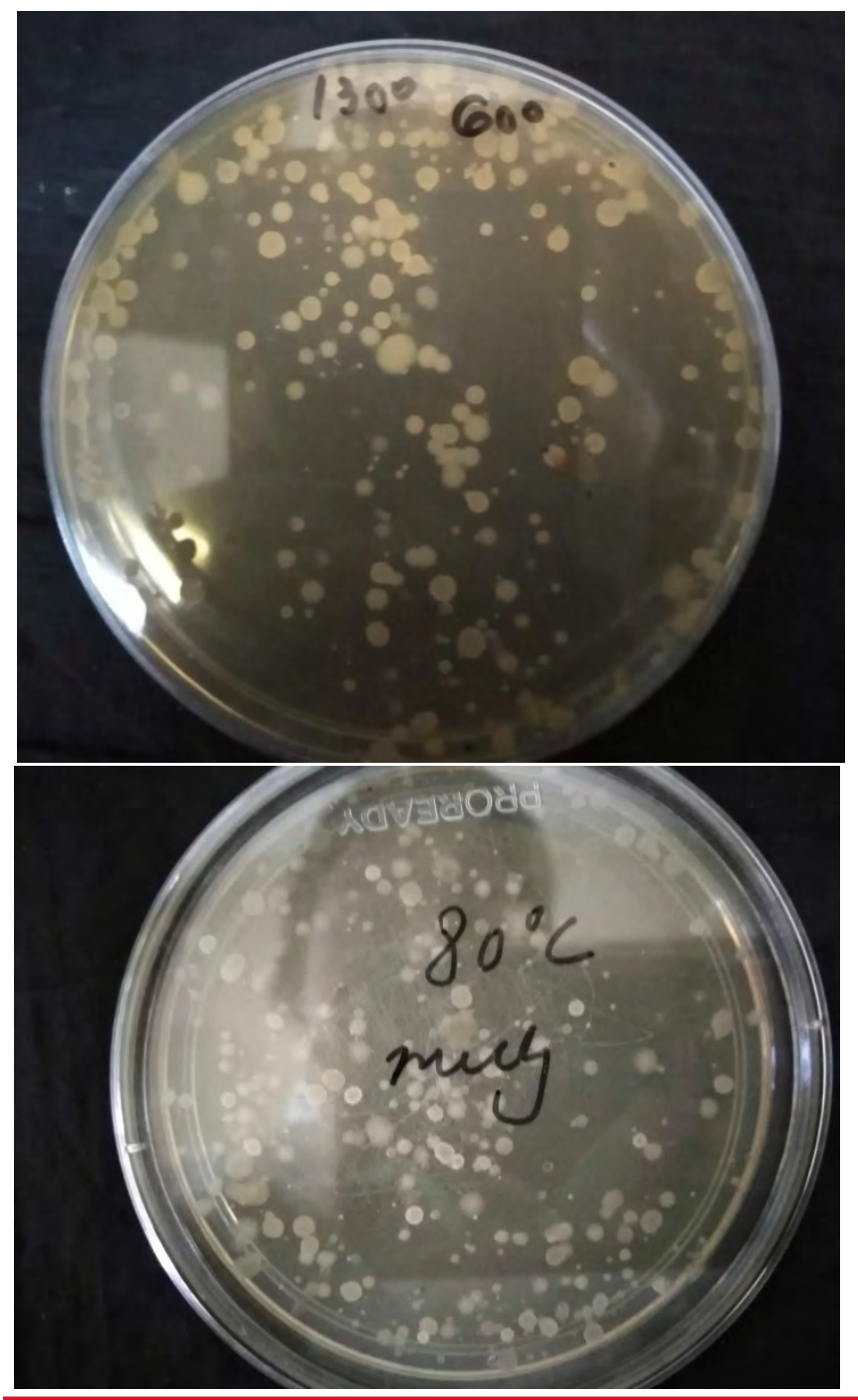

Figure 7: Microorganisms viability after fluidized bed drying at 60 and $80^{\circ} \mathrm{C}$

\subsection{Microorganisms viability}

The basic concept of this paper is the application of fluidized bed for sludge stabilization or its modification for further use. Fluidized beds represent innovative way of performing the processes in this field, which provide a large contact area between the phases and increase the rate of mass, heat and momentum transfer.
In the case of reapplication, the sludge is treated so that it retains its useful components. To preserve the biological characteristics of the sludge, drying process in which the microorganisms are transformed into the state without the surrounding moisture that is necessary for their growth is usually applied. In this case, care must be taken to prevent the inactivation of the microorganisms, i.e. to preserve the viability of the cells for re-use.

Drying in fluidized bed with short residence time ensure the preservation of cell viability even at elevated temperatures, which was confirmed by microorganism growth, as shown in Fig. 7, for drying temperatures of 60 and $80^{\circ} \mathrm{C}$.

\section{4}

\section{CONCLUSIONS}

In this paper, experimental investigation of the efficiency of drying of municipal waste water treatment sludge was performed in a pilot scale fluidized bed dryer with inert glass particles of the capacity up to $20 \mathrm{kgH} 2 \mathrm{O} / \mathrm{h}$ of evaporated water. Inert particles used were glass spheres of the diameter of $1.94 \mathrm{~mm}$. Waste water treatment sludge with dry mass concentration from 1-4\% was used in the experiments.

Drying of solutions, suspensions and pastes in a fluidized bed of inert particles is a simple and very effective technique for non-sticky materials that do not adhere permanently to the inert particles. It was shown that this technique can be efficiently used for waste water treatment sludge. Final product moisture content decreases with an increase in drying temperature and this relationship depends on dried material characteristics. Inlet air temperature, superficial air velocity and static bed height can be set in such way to approach the optimum feed rate defined by energy efficiency and product moisture content.

Drying in fluidized bed with short residence time ensure the preservation of cell viability even at elevated temperatures, which was confirmed by microorganism growth after the drying process.

\section{Acknowledgment}

Financial support of the Serbian Ministry of Education and Science (Project ON172022) is gratefully acknowledged.

\section{References}

[1] Fytili, D., A. Zabaniotou, Utilization of sewage sludge in EU application of old and new methods-A review, Renewable and Sustainable Energy Reviews, 12 (2008), 1, pp. 116-140.

[2] Shin, Y.S., H.C. Kim, H.S. Chun, Drying of water treatment process sludge in a fluidized bed dryer, Korean Journal of Chemical Engineering, 17 (2000), 1, pp. 22-26.

[3] Shiyuan, L., L. Yunyu, L. Qinggang, Z. Jianguo, Y. Yao, B. Shaolin, Integrated drying and incineration of wet sewage sludge in combined bubbling and circulating fluidized bed units, Waste Management, 34 (2014), 12, pp. 2561-2566.

[4] Mujumdar, A.S., Handbook of Industrial Drying 4th Ed., Marcel Dekker Inc., New York, 2014.

[5] Kudra, T., A.S. Mujumdar, Advanced Drying Technologies 2nd Ed., Marcel Dekker Inc., New York, 2009.

[6] Kudra, T., A.S. Mujumdar, Special drying technologies and novel dryers, In Handbook of Industrial Drying 4th Ed., Marcel 
Dekker Inc., New York, 2014.

[7] Grbavcic, Z.B., Z.L. Arsenijevic, R.V. Garic-Grulovic, Drying of slurries in fluidized bed of inert particles, Drying Technology, 22 (2004), 8, pp. 1793-1812.

[8] Arsenijević, Z., Drying suspension in the industry, in Serbian 1st Ed., Andrejevic Foundation, Belgrade, Serbia, 2008.

[9] Pan, Y.K., J.G. Li, L.J. Zhao, W.H. Ye, A.S. Mujumdar, T. Kudra, Performance characteristics of the vibrated fluid bed of inert particles for drying of liquid feeds, Drying Technology, 19 (2001), pp. 2003-2018.

[10] Kutsakova, V.E., Drying of liquid and pasty products in a modified spouted bed of inert particles, Drying Technology, 22 (2004), pp. 2343-2350.

[11] Chen, G., P. Lock Yue, A.S. Mujumdar, Sludge dewatering and drying, Drying Technology, 20 (2002), 4-5, pp. 883-916.

[12] Yun, T.M., I. Puspasari, S.M. Tasirin, M.Z.M. Talib, W.R.W. Daud, Z. Yaakob, Drying of oil palm frond particles in a fluidized bed dryer with inert medium, Chemical Industry \& Chemical Engineering Quarterly, 19 (2013), 4, pp. 593-603.

\section{Authors}

Mihal ĐURIŠ

Institute of Chemistry, Technology and Metallurgy, University of Belgrade, Njegoševa 12, Belgrade mdjuris@tmf.bg.ac.rs

\section{Zorana ARSENIJEVIĆ}

Institute of Chemistry, Technology and Metallurgy, University of Belgrade, Njegoševa 12, Belgrade

\section{Dragan POVRENOVIĆ}

Faculty of Technology and Metallurgy, University of Belgrade, Karnegijeva 4, Belgrade

\section{Tatjana KALUĐEROVIĆ RADOIČIĆ}

Faculty of Technology and Metallurgy, University of

Belgrade, Karnegijeva 4, Belgrade

\section{Izdanja SMEITS-a}

\section{Сушаре / Теорија и задаци / Прво издање}

Сушење је једна од многобројних процесних операција које су сврстане у основне процесне операције (механичке, хидромеханичке, топлотне, дифузионе, хемијске и биохемијске), али се због свог значаја и заступљености у технолошким процесима издваја као посебна целина. У великом броју случајева добијање одређених производа заснива се првенствено на процесу сушења као основној процесној операцији.

Као резултат вишегодишњег рада аутора у настави и инжењерској пракси у овој области припремљен је материјал за књигу “Сушаре - теорија и задаци”, а материја обрађена у књизи постала је и саставни део предмета Сушаре на мастер студијама Модула за процесну технику и заштиту животне средине на Машинском факултету у Београду.

Књига обухвата десет поглавља: (1) Прорачун параметара влажних материјала; (2) Термодинамичка својства влажног ваздуха; (3) Материјални и топлотни биланс процеса сушења; (4)Прорачун параметара сушења, сушење разблаженим димним гасовима; (5) Прорачун параметара сушења са међузагревањем и рециркулацијом ваздуха; (6) Прорачун сушара при шаржном процесу сушења; (7) Прорачун цевних сушара; (8) Прорачун сушења у континуалним коморама за сушење са директним загревањем; (9) Прорачун ротационих сушара и (10) Прорачун сушара са флуидизованим и фонтанским слојем, са укупно 119 рачунских примера. На почетку сваког поглавља приказан је преглед коришћених једначина са допунама које су дате у осам прилога.

Надамо се да ће ова књига бити од помоћи и стручњацима који раде на пословима пројектовања и експлоатације постројења у којима се одвија процес сушења, као и студентима техничких факултета у чијим наставним програмима је ова област заступљена.

Како се ове године навршава 60 година од почетка наставе из области процесне технике на Машинском факултету у Београду, издавање књиге представља мали допринос овом јубилеју и омаж свим прегаоцима из области процесне технике са и ван Машинског факултета у Београду.

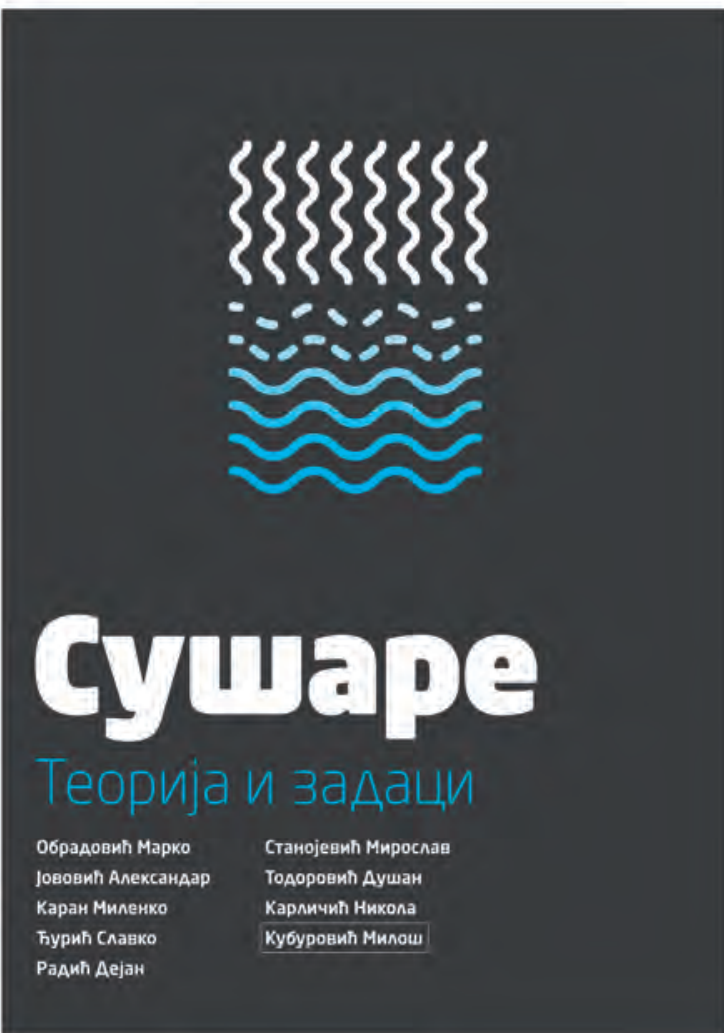

